\title{
DESTINASI BRANDING KAMPUNG LAWANG SEKETENG SEBAGAI WISATA KULINER
}

\author{
Nurul Aini Raosindah Maruto1, Anam Miftakhul Huda2 \\ Program Studi Ilmu Komunikasi, Fakultas Ilmu Sosial dan Hukum \\ Universitas Negeri Surabaya \\ nurulmaruto16041184005@mhs.unesa.ac.idı,anamhuda@unesa.ac.id2
}

\begin{abstract}
ABSTRAK
Kampung wisata Surabaya merupakan suatu bentuk struktur kehidupan masyarakat dengan potensi yang menjadi ciri khas dan tradisi dari warga kampung tersebut yang telah diresmikan oleh Pemerintah. Hal tersebut mendukung upaya dari potensi karakteristik dan tradisi yang berbeda-beda. Penelitian ini membahas tentang strategi dan program apa saja yang telah disusun untuk membranding Kampung Lawang Seketeng sebagai wisata kuliner. Pembentukan pada destinasi branding diikuti dengan wisata Heritage seperti Langgar dukur kayu yang merupakan icon utama dari kampung lawang seketeng. Penelitian ini merupakan penelitian Studi kasus dengan menggunakan metode kualitatif. Selain itu juga dilakukan teknik observasi dan wawancara dengan tim pengelola yang dinamakan Tim POKDARWIS. Kampung lawang seketeng merupakan kampung wisata yang baru diresmikan pada tahun 2019 sehingga hasil dari pembahasan penelitian ini, berdasarkan konsep tahapan destinasi branding yang ditemukan yaitu strategi dari tim pengelola untuk mengembangkan wisata kulinernya dengan aktif membuat program kuliner yang diadakan di kampung lawang seketeng dan aktif mempromosikan kuliner melalui aplikasi driver online maupun media sosial. Keterkaitan dari wisata Heritage sangat berdampak pada wisata kuliner yang mampu memberikan jumlah peminat dari wisatawan. Stretegi tersebut didukung dengan adanya tiga jenis kuliner khas kampung lawang seketeng yaitu Rujak topak, Sate manggul, dan Martabak mie
\end{abstract}

Kata Kunci : Destinasi Branding, kampung lawang seketeng, wisata kuliner surabaya

\begin{abstract}
Surabaya tourism village is a form of community life structure with potentials that are characteristic and traditions of the villagers that have been inaugurated by the Government. This supports efforts from the potential of different characteristics and traditions. This study discusses the strategies and programs that have been prepared to compare Kampung Lawang Seketeng as culinary tourism. The formation of the branding destination is followed by Heritage tourism such as Langgar dukur kayu which is the icon mainof the Lawang Seketeng village. This research is a case study research using qualitative methods. In addition, observation and interview techniques were also conducted with the management team called the POKDARWIS Team. Lawang Seketeng a tourist village, which was inaugurated in 2019 so that the results of this research study, based on the concept stages of destination branding it was found that the strategy of the management team was to develop its culinary tourism by actively creating a culinary program held in the village of Sekang Seketeng and actively promoting culinary through applications online driver and social media. The linkages of Heritage tourism greatly affect culinary tourism which is able to provide the number of enthusiasts from tourists. The stretch is supported by the existence of three types of culinary specialties in the village of Lawang Seketeng namely Rujak Topak, Satay Manggul, and Martabak Mie
\end{abstract}

Keywords: destination Branding, Lawang seketeng,village, culinary tour Surabaya

\section{PENDAHULUAN}

Pariwisata di Indonesia memberikan keuntungan bagi sumber devisa Negara Indonesia, yang telah dijelaskan pada UU No. 10 Tahun 2009 menjelaskan tentang Kepariwisataan di Negara Indonesia(Anonim, 2009). Pada peraturan tersebut, terdapat pasal 1 ayat 3 meneyebutkan bahwa 
pariwisata merupakan kegiatan wisata yang didukung dengan fasilitas dan layanan yang disediakan oleh masyarakat, pemerintah, dan stakeholder lainnya (Jaya \& Ariana, 2009). Hal ini membuat sektor pariwisata kota mengharuskan kepada pemerintah untuk terus mengembangkan potensi wisata yang dimiliki. Tri Rismaharini selaku Walikota Surabaya mengembangkan Kota Surabaya menjadi sektor pariwisata dengan potensi di setiap daerah di Kota Surabaya untuk dapat menjadi destinasi wisata baru serta menambah daya tarik wisatawan saat berada di Kota Surabaya. Walikota Surabaya mengeluarkan surat keputusan No. 188.45/30//436.1.2/2006, surat tersebut berisi tentang pembentukan dari Surabaya Tourism Promotion Board (STPB). Surabaya tourism promotion board merupakan sebuah organisasi Non-profit yang memiliki legalitas untuk mempromosikan destinasi pariwisata di Kota Surabaya (Satriya, 2011). Tujuan dari surabaya promotion board adalah mempromosikan kota Surabaya sebagai destinasi pariwisata yang berfokus dalam bidang promosi (Khairunisa, 2015)

Mengembangkan potensi di setiap daerah, dapat menjadikan aspek destinasi pariwisata yang menguntungkan (Kusuma, 2018). Sehingga pariwisata sendiri merupakan sektor bidang yang menambah pendapatan bagi suatu daerah tersebut. Pariwisata juga dapat meningkatkan perekonomian warga dengan meningkatkan tenaga kerja dari warga lokal sendiri (Priyadi, 1993). Hal tersebut dapat membantu devisa bagi Negara Indonesia yang merupakan industri terbesar dalam pertumbuhan dan pengembangan potensi di Indonesia (Hasan, 2015). Potensi wisata yang dimiliki Kota Surabaya dapat menjadi destinasi baru untuk membranding pariwisata Kota Surabaya. Daerah perkampungan yang telah ditetapkan sebagai kampung wisata memiliki daya Tarik serta karakteristik di setiap kampung wisata. Pariwisata di Indonesia memiliki beragam jenis wisata yaitu wisata kuliner, wisata alam, wisata edukasi, dan wisata bermain. Sehingga di setiap kampung wisata memiliki keunikan dan karakteristik yang berbeda-beda (Nuryanti, 2003). Destinasi branding bagi kampung wisata memiliki hubungan antara pengunjung dengan destinasi pariwisata. Hal tersebut dapat meningkatkan loyalitas dan respons positif dari pengunjung saat mendatangi kampung wisata (Ariando, 2015). Perbedaan karakteristik serta tradisi dari setiap kampung wisata dapat membedakan dengan kampung wisata lainnya.

Kampung Lawang Seketeng Surabaya merupakan Kampung Wisata yang telah diresmikan oleh Pemerintah Kota Surabaya bersama Surabaya Creative Network pada bulan 11 November 2019. Kampung wisata tersebut terletak di Kelurahan Peneleh, Kota Surabaya, Jawa Timur. Kampung Lawang Seketeng merupakan kampung peninggalan bangunan bersejarah, dengan adanya bangunan Langgar Dukur Kayu sebagai tempat mengaji Presiden Soekarno saat beliau masih kecil. terdapat juga Terakota, Sumur Tua, Rumah Kayu, serta Rumah Puing. Tidak hanya bangunan sejarah yang menjadi keunikan dari Kampung Lawang Seketeng, melainkan wisata kuliner juga terdapat di dalam kampung tersebut yaitu adanya makanan serta jajanan khas dari Kampung Lawang seketeng untuk dapat menjadi keunikan pada kampung dengan wisata kuliner yang dimilikinya (Zahroh, 2019). Kuliner khas dari kampung Lawang Seketeng adalah Sate Manggul, Rujak Topak, dan Martabak Mie. Ketiga kuliner tersebut menjadi icon wisata kuliner untuk berkunjung di Kampung Lawang Seketeng.

Potensi kuliner Kampung Lawang Seketeng menjadi branding kampung wisata dengan keunikan yang dimiliki, hal tersebut diikuti dengan potensi dari Kampung Lawang Seketeng dapat meningkatkan jumlah pengunjung setelah diresmikannya Kampung Wisata oleh Pemerintah Kota Surabaya pada bulan November tahun 2019. Berbagai acara festival kuliner diadakan oleh Pemerintah kota Surabaya, menjadi bentuk pemasaran dari kampung wisata Lawang Seketeng untuk membranding wisata kuliner utama yaitu Sate Manggul, Rujak Topak, dan Martabak mie (Jannah, 2019).

Branding yang dilakukan oleh tim pengelola Kampung Wisata Lawang Seketeng dengan menyusun program kegiatan yang bekerja sama dengan Komunitas Love Suroboyo. Berbagai program yang telah direncanakan seperti halnya pada program dongeng yang ditujukan kepada anak usia dini, hal tersebut merupakan upaya branding yang dilakukan oleh pengelola untuk meningkatkan jumlah pengunjung serta membranding Kampung Lawang Seketeng. Setelah pembukaan atau grand opening tanggal 11 November 2019, Kampung Lawang Seketeng buka pada hari Sabtu hingga Senin. 
Wisatawan untuk berkunjung tidak mengalami peningkatan yang cukup drastis dan signifikan, sehingga beberapa wisatawan yang mengunjungi kampung tersebut sekedar meneliti wisata sejarah dan beberapa wisatawan hanya mengunjungi sentra kuliner yang terdapat di dalam Kampung Lawang Seketeng. Program rutin yang diadakan setiap tahun sekali saat lebaran yaitu festival adhun, yang mana seluruh warga lokal pada saat lebaran memasak Adhun merupakan kuliner khas Madura. Festival kuliner tersebut menjadi strategi dalam memasarkan kampung Lawang Seketeng.

Tim pengelola kampung lawang seketeng membranding kampung tersebut dengan memberi sebutan Kampung Heritage dan kampong wisata kuliner, hal ini merupakan perpaduan untuk meningkatkan jumlah pengunjung dari potensi wisata kuliner yang dimiliki. Hal tersebut merupakan langkah branding bagi pengelola untuk terus meningkatkan dan menarik perhatian pengunjung.Kuliner khas yang dimiliki merupakan bahan dalam membranding kampung Lawang Seketeng sebagai wisata kuliner. Strategi branding tersebut bertujuan untuk pengunjung yang berwisata kuliner di kampung Lawang Seketeng juga ikut merasakan suasana bersejarah saat Soekarno kecil. Tim pengelola dari Kampung Lawang Seketeng membuat program dalam mengembangkan kulinernya yaitu mengikuti festival kuliner di Kota Surabaya untuk mempromosikan tiga kuliner khas Kampung Lawang Seketeng dengan mengenakan baju keteng yang merupakan pakaian sebagai ciri khas Warga Kampung Lawang Seketeng saat menghadiri atau mengikuti acara di Kota Surabaya. Program kuliner lainnya yang direncanakan oleh pengelola yaitu mengadakan festival UKM kuliner di Kota Surabaya, bertempat di Kampung Lawang Seketeng. Upaya tersebut merupakan langkah dalam membranding serta meningkatkan jumlah wisatawan untuk mengunjungi Kampung Lawang Seketeng sebagai wisata kuliner dengan icon kuliner utama yaitu Sate Manggul, Rujak Topak, dan Martabak Mie.

Penelitian dengan topik yang sama tentang Destinasi branding Bawean sebagai pulau wisata oleh Novi Nur Anggraini tahun 2018, S1 Ilmu Komunikasi Sekolah Tinggi Komunikasi Almamater Wartawan Surabaya. Penelitian tersebut membahas tentang strategi dari destinasi branding Bawean sebagai pulau wisata dengan menggunakan teori pemasaran 7P, serta analisis SWOT. Penelitian ini menghasilkan berbagai macam wisata yang ada di Pulau Bawean dalam mengembangkan destinasi wisata (Anggraini, 2018). Penelitian selanjutnya yang merupakan acuan bagi penulis untuk menjelaskan penelitian ini yaitu oleh Anindita Fitria Dewi Tahun 2009, S1 Desain komunikasi visual, Universitas Sebelas Maret Surakarta. Penelitian tersebut menjelaskan tentang Destinasi branding dari kampung sate desa Ambal Resmi Kabupaten Kebumen, terhadap wisata kuliner yang dimiliki. Menggunakan metode kualitatif, dari penelitian ini menghasilkan konsep mengenai logo, tagline, desain visual dari kampung Desa ambal resmi. Adapun konsep tersebut merupakan tujuan dalam membranding destinasi wisata kulinernya yang telah disusun oleh pemerintah Kabupaten Kebumen (Dewi, 2009). Penelitian selanjutnya yang merupakan acuan dalam menemukan konsep destinasi branding untuk menyelesaikan penelitian ini yaitu oleh Ayu Via Dewiyanti Tahun 2016, S1 Ilmu Komunikasi, Universitas Islam Negeri Sunan Kalijaga Yogyakarta. Penelitian tersebut berjudul Tahapan destinasi branding dalam meningkatkan jumlah pengunjung (Studi Deskriptif Kualitatif pada UNESCO Global Geopark Gunung sewu geo area Kabupaten Pacitan. Menjelaskan tahapan dalam destinasi branding pada UNESCO global geopark gunung sewu geo area untuk meningkatkan jumlah pengunjung. Melalui teori yang dijadikan sebagai referensi dari teori destinasi branding oleh Morgan dan Pitchard, dalam penelitian ini juga menjelaskan lima tahapan destinasi branding untuk meningkatkan jumlah pengunjung yaitu dengan dimulai dari tahapan Market investigation dan Analysis strategic recommendation, Barnd identity development, brand launch, brand implementation, monitoring evaluation dan review. Tahapan tersebut merupakan alasan dalam meningkatkan jumlah pengunjung (Dewiyanti, 2016).

Perbedaan pembahasan penelitian terdahulu dengan penelitian ini yaitu, di mana peneliti ingin mengkaji lebih dalam tentang strategi dan program apa saja dengan menggunakan lima tahapan dalam destinasi branding. Potensi wisata kuliner kampung Lawang Seketeng terhadap destinasi branding, diharapkan mampu memberikan informasi mengenai tema pembahasan yang diambil oleh peneliti. Berbagai macam wisata kuliner di Surabaya, menjadikan kampung Lawang Seketeng memiliki proses 
destinasi branding dalam meningkatkan keunikan kuliner yang menjadi icon Kampung Lawang Seketeng.

Teori komunikasi pariwisata dalam pembahasan artikel ini dapat mendukung kegiatan dalam mempromosikan Kampung Lawang Seketeng. Peran dari komunikasi pariwisata diketahui dapat mendukung devisa bagi Negara Indonesia, hal tersebut dapat meningkatkan pertumbuhan perekonomian bagi warga lokal yang tinggal di daerah pariwisata (Marpaung, 2002). Bagi suatu destinasi hal tersebut dapat memberikan tambahan pendapatan dengan meningkatnya jumlah kunjungan wisata karena adanya komunikasi pariwisata. Peran komunikasi pariwisata dari bidang pendidikan yaitu informasi mengenai letak suatu objek wisata dan keunggulan dari destinasi pariwisata dapat menjadi edukasi atau pengetahuan tentang wisata tersebut. Pendidikan tentang pariwisata dapat menjadi bahan referensi atau masukan bagi pengelola untuk mengembangkan objek wisata dengan tujuan agar dapat menambah jumlah pengunjung wisatawan. Bidang budaya dari peran komunikasi pariwisata merupakan sebuah edukasi dalam memahami tradisi dari warga lokal di tempat pariwisata. Hal tersebut, dapat menciptakan interaksi dari pengunjung kepada warga lokal untuk mengetahui kebudayaan dan kepercayaan yang dianut oleh warga lokal.

Pariwisata merupakan suatu tempat destinasi yang dikunjungi oleh seseorang saat melakukan perjalanan untuk berwisata. Kegiatan tersebut merupakan tujuan dalam memenuhi kebutuhannya. Sedangkan seseorang yang melakukan kegiatan perjalanan dengan tujuan berwisata dinamakan sebagai Wisatawan (Marpaung, 2002). Suatu proses bepergian sementara dari wisatawan untuk menuju ketempat wisatawa merupakan pengertian pariwisata dengan adanya dorongan seperti kepentingan ekonomi, sosial, budaya, politik, agama, maupun kepentingan pendidikan. Pariwisata disuatu daerah merupakan destinasi yang dibuat dengan tujuan memberikan keuntungan bagi warga daerah untuk dapat membranding daerah wisata tersebut (Pendit, 2003). Branding dalam kampung wisata merupakan bentuk kegiatan dari adanya nama, logo, potensi karakteristik, serta tradisi masyarakat sebagai pembeda dari setiap kampung. Branding merupakan kegiatan dalam proses pembentukan nama dari suatu tempat. Dalam proses tersebut termasuk membuat identitas serta logo, yang itu adalah proses dari kegiatan branding (Vasyl \& Julio, 2014). Proses dalam membranding yaitu seperti mendesain, merencanakan, dan mempromosikan hasil yang telah disusun dengan tujuan membangun reputasi di setiap wisata yang dikelola (Anholt, 2007). Adanya perkenalan untuk menjadi bahan promosi di segmen pasar pariwisata sendiri juga menjual citra dari produk yang dilalui dari proses konstruksi sosial.

Teori dari Destination branding dalam penelitian ini merupakan usaha untuk mengubah persepsi seorang terhadap suatu tempat atau tujuan termasuk dalam melihat perbedaan sebuah tempat untuk dipilih sebagai tujuan. Brand Destinasi memiliki arti yang tidak hanya sebatas slogan, tagline, logo destinasi, dan lainnya saja. Brand suatu destinasi haruslah mencakup keseluruhan destinasi yang di dalamnya terdapat nilai, filosofi, budaya, serta harapan masyarakat atau stakeholder di dalam destinasi tersebut. Komponen dalam pembentukan destination branding yaitu pariwisata, people, governance, export, investment, culture and heritage (Farhanas, 2018). Tahapan destinasi branding menurut Morgan dan Pritchard dalam penelitian Ayu Via Dewiyanti, terdapat lima tahapan yang dilakukan yaitu adanya riset dari pemasaran dan strategi analisis mengenai kampung wisata. Adapun penyusunan dalam pemetaaan potensi dasar yang dimiliki, serta hal-hal apa saja yang dapat dikembangkan sebagai strategi untuk mempromosikan kampung wisata. Tahap kedua yaitu pengembangan kampung wisata yang diresmikan oleh pemerintah, pada tahapan ini dibentuk dengan adanya visi serta misi yang dibentuk setelah diresmikan oleh pemerintah. Tahap ini merupakan pengembangan dalam meningkatkan identitas untuk dapat dikenal oleh wisatawan atau publik terhadap Kampung Lawang Seketeng. Tahap ketiga adalah pengenalan potensi dari Kampung Lawang Seketeng, dengan cara mempromosikan melalui media pemasaran, media sosial, website, pembuatan film, jurnalis dan event organizer. Hal tersebut merupakan langkah dalam mempromosikan kampung wisata melalui berbagai media. Adapun tahap brand implementation yang merupakan bentuk usaha untuk mengintegrasikan semua pihak yang terlibat dalam pembentukan branding dari kampung wisata. Tahap terakhir yaitu mengevaluasi dari pemantauan respon 
pengunjung terhadap kampung wisata. Monitoring tersebut berisi tentang penyimpangan, kekurangan, dan lain-lain dari kampung lawang seketeng, yang kemudian hasil monitoring tersebut kemudian dievaluasi untuk dapat dijadikan sebagai saran dalam mengolah kampung lawang seketeng.

Kampung Lawang Seketeng merupakan kampung berawal dari kehidupan bersejarah, di mana kampung tersebut merupakan kampung Presiden pertama Indonesia yaitu Ir. Soekarno. Banyaknya bangunan bersejarah serta rumah tua berada di kampung tersebut. Membuat wisatawan mengunjungi Kampung Lawang Seketeng setelah diresmikan kampung wisata yang dapat dikunjungi wisatawan untuk meneliti bangunan bersejarah serta mengamati kehidupan Presiden Soekarno sewaktu kecil. Tanpa menghilangkan sejarah awal yang ditemukan, pengelola mengubah branding Kampung Lawang Seketeng dengan awal sebagai Kampung Heritage hingga kini merupakan wisata kuliner. Transformasi tersebut merupakan langkah branding bagi pengelola untuk terus meningkatkan dan menarik perhatian pengunjung. Kuliner khas yang dimiliki merupakan bahan dalam membranding Kampung Lawang Seketeng sebagai wisata kuliner. Strategi branding tersebut bertujuan untuk pengunjung yang berwisata kuliner di Kampung Lawang Seketeng juga ikut merasakan suasana bersejarah saat Soekarno kecil.

\section{METODE PENELITIAN}

Penelitian ini merupakan penelitian dengan metode studi kasus dengan pendekatan deskriptif kualitatif. Penelitian ini bertujuan untuk mendapatkan informasi secara mendalam melalui data yang diperoleh dari proses wawancara dengan narasumber (Kountur, 2007). Penelitian kualitatif merupakan penelitian yang menghasilkan data deskriptif dari adanya subjek penelitian dengan berupa uraian tertulis dan lisan, hal tersebut dapat diamati dari perilaku maupun fenomena yang tejadi di masyarakat seperti perilaku, persepsi, dan motivasi (Moleong, 2007). Sumber data dari penelitian ini berasal dari wawancara langsung, dan dilanjutkan dengan wawancara online melalui media sosial yaitu Whatsapp, studi dokumen dan rekaman arsip dari pengelola Kampung Lawang Seketeng.

Penelitian ini dilakukan terhitung mulai sejak 29 Januari 2020, peneliti melakukan pra survey dan dilanjut dengan meneliti beberapa aktivitas warga Kampung Lawang Seketeng hingga 30 Mei 2020. Lokasi penelitian berada di Kampung Lawang Seketeng, terletak di Jalan Peneleh, Kecamatan Genteng, Kota Surabaya, Jawa Timur. Narasumber dari penelitian ini adalah Suwartono yang merupakan Tim Pengelola serta juga menjadi Ketua RW dan Andre merupakan Tim POKDARWIS Kampung Wisata Lawang Seketeng Surabaya. Pengambilan data dilakukan dengan teknik wawancara secara mendalam dengan pengelola dan terstruktur, di mana peneliti bereksekusi lebih bebas dalam mengajukan pertanyaan kepada narasumber (Sugiyono, 2011). Wawancara oleh beberapa informan dilakukan dengan bertatap muka secara langsung dan dilanjutkan wawancara melalui media sosial

Penelitian dengan menggunakan analisis dari model Miles dan Huberman tahun 1984 dilakukan di lapangan ini menjelaskan tentang menganalisis data kualitatif secara interaktif serta berlangsung terus menerus hingga selesai (Miles, 1984) dengan melalui tahapan mereduksi data yang diperoleh dari narasumber kampung lawang seketeng, menyajikan data dengan uraian singkat, menarik kesimpulan dan melakukan verifikasi data (Sugiyono, 2011). Kemudian penelitian ini akan di uji kebsahannya dengan menggunakan triangulasi sumber data yang membandingkan hasil wawancara dengan hasil temuan dari peneliti untuk membentuk destinasi branding Kampung Lawang Seketeng sebagai wisata kuliner.

\section{HASIL DAN PEMBAHASAN}

\section{A. Sekilas Kampung Lawang Seketeng Surabaya}

Kampung wisata atau yang dapat disebut dengan desa wisata merupakan suatu kegiatan masyarakat yang terstruktur dalam bentuk atraksi, akomodasi, serta fasilitas pendukung dari potensi yang ada di kampung wisata (Antara \& Arida, 2015). Kampung Lawang Seketeng Surabaya terletak di Jalan Peneleh Kecamatan Genteng Kota Surabaya. Diresmikan pada tanggal 11 November 2019 
sebagai kampung wisata sejarah Surabaya. Kampung tersebut terbagi menjadi enam gang dengan memiliki peninggalan sejarah yang berbeda-beda di setiap wilayah gang Kampung Lawang Seketeng. Pada gang pertama terdapat peninggalan sejarah yang menjadi keunikan dari Kampung Lawang Seketeng adalah adanya sumur jobong majapahit, gang kedua terdapat wisata religi yaitu makam Syekh Zen Zini Assegaf yang merupakan seorang ulama dan di area makam juga terdapat lumpang batu besar, pada gang ketiga dengan wisata religi yang dimiliki terdapat makan Mbah Pitono merupakan seorang guru ngaji dari Bung Karno, tidak hanya wisata religi di gang ketiga juga terdapat sumur tua yang berusia lebih dari 100 tahun. Pada gang keempat terdapat rumah jengki dibangun tahun 1930 dengan rancangan arsitektur dan rumah tersebut pernah menjadi tempat shooting film tahun 2018 "Terbang Menembus Langit" terdapat rumah puing yang juga merupakan wisata sejarah yang ada di Kampung Lawang Seketeng berdiri sejak tahun 1930 dengan pilar-pilar besar, serta bentuk lengkung diatas pintu yang menambah daya tarik dari rumah puing tersebut, gang kelima terdapat wisata peninggalan sejarah yaitu adanya terakota merupakan saluran air yang dibangun pada tahun 1930, gang keenam terdapat rumah kayu yang mana pada rumah tersebut memiliki atap seng dengan masih menyimpan bekas tembakan dari pesawat tempur ditahun 1930-an, tidak hanya wisata peninggalan sejarah gang enam juga memiliki wisata religi yang menjadi ikon dari Kampung Lawang Seketeng yaitu langgar dukuh kayu merupakan tempat ibadah dan tempat mengaji Bung Karno saat kecil dibangun pada tahun 1893, bangunan ini terdiri dari 2 lantai dan sampai saat ini mushola tersebut masih digunakan oleh leluhur warga lokal kampung lawang seketeng. Tepat di depan langgar dukuh kayu, terdapat sentra kuliner dari Kampung Lawang Seketeng yang menjual beberapa makanan khas dari kampung tersebut. Selain dari wisata religi dan wisata sejarah yang dimiliki, Kampung Lawang Seketeng memiliki wisata kuliner dengan makanan khas yang dimiliki yaitu rujak topak, sate manggul, martabak mie. Berbagai macam kuliner tersebut berasal dari Pulau Madura, di karenakan mayoritas warga kampung lawang seketeng berasal dari Madura.

\section{Asal usul POKDARWIS Kampung Lawang Seketeng}

Salah satu adanya program dari Kementerian Pariwisata yaitu dengan memberdayakan masyarakat lokal dengan membentuk kelompok sadar wisata atau kelompok penggerak pariwisata di suatu daerah (Razzaq et al., 2019). Tim pengelola kampung lawang seketeng dinamakan sebagai Kelompok Sadar Wisata atau yang sering disebut sebagai POKDARWIS. Kelompok Sadar Wisata merupakan komponen dari masyarakat dengan memiliki peran serta kontribusi yang penting dalam mengelola kepariwisataan di Kampung Lawang Seketeng. Tim POKDARWIS memiliki peran sebagai penggerak dalam merubah pola pikir masyarakat dan mendukung kegiatan wisata untuk mensejahterakan warga Kampung Lawang Seketeng (Rahim, 2012). Keberadaan POKDARWIS di Kampung Lawang Seketeng telah didukung dan dibina oleh komunitas serta pemerintah untuk dapat berperan aktif dalam meningkatkan serta menciptakan suasana dalam kampung wisata yang dikelola (Iskandar, 2017). Tujuan dibentuknya Kelompok Sadar Wisata adalah sebagai mitra dari pemerintah dengan warga lokal dan meningkatkan kinerja masyarakat serta menciptakan sapta pesona kampung wisata (Suryawan, 2016). Pada Kampung Lawang Seketeng memiliki tim Pokdarwis yang beranggotakan 3 orang bernama Machmud sebagai ketua Pokdarwis, Andre, dan Purwantono yang sekaligus merupakan ketua RW di Kampung Lawang Seketeng. Ketiga anggota tersebut memiliki peranan disetiap wilayah dari Kampung Wisata Lawang Seketeng. Fungsi Pokdarwis dalam kegiatan kepariwisataan adalah Sebagai penggerak Sadar Wisata di lingkungan wilayah kampung wisata dan sebagai Mitra Pemerintah Pusat dan Pemerintah Daerah (kabupaten/kota) dalam upaya perwujudan dan pengembangan Sadar Wisata di daerah. Pokdarwis ini merupakan kelompok swadaya dan swakarsa masyarakat yang dalam aktivitas sosialnya berupaya untuk:

a. Meningkatkan pengetahuan tentang kepariwisataan kepada masyarakat lokal serta merubah pola pikir masyarakat tentang perubahan dari adanya kampung wisata

b. Mendukung peranan dan partisipasi warga dalam pembangunan kepariwisataan. Mengubah pola pikir serta kebiasaan dari warga lokal untuk lebih aktif dalam bersosialisasi serta mengikuti kegiatan di Kampung Lawang Seketeng 
c. Meningkatkan nilai manfaat kepariwisataan bagi masyarakat/anggota Pokdarwis. Memberikan sosialisasi tentang adanya kampung wisata dan memberikan arahan untuk masyarakat lokal

d. Mensukseskan pembangunan kepariwisataan dengan membuat program kegiatan untuk Kampung Lawang Seketeng, dan mengembangkan potensi yang dimiliki oleh masyarakat lokal di Kampung Lawang Seketeng

2. Potensi Branding Kampung Lawang Seketeng Surabaya

Destination branding merupakan usaha dalam merubah persepsi dari masyarakat terhadap suatu tempat pariwisata termasuk dalam melihat perbedaan dari kampung wisata dengan kampung wisata lainya yang ada di kota Surabaya dipilih sebagai tujuan pariwisata. Beberapa peninggalan sejarah yang menjadi daya tarik wisatawan dalam berkunjung di Kampung Lawang Seketeng, diantaranya yaitu :

1. Terakota

Terdapat beberapa terakota yang ada di sepanjang jalan Kampung Lawang Seketeng terakota merupakan sebuah pipa saluran air yang terbuat dari tanah liat yang sudah tertata rapi yang ditemukan pada gang 4 serta gang 3 di Kampung Lawang Seketeng. Terakota dibangun pada thun 1930, dengan ukuran panjang $81 \mathrm{~cm}$, diameter sambungan $52 \mathrm{~cm}$, dan keliling $40 \mathrm{~cm}$. pada gang 3 terakota dibangun dengan ukuran panjang $106 \mathrm{~cm}$, diameter sambungan $58 \mathrm{~cm}$, dan keliling $42 \mathrm{~cm}$.

2. Sumur tua

Kampung Lawang Seketeng memiliki beberapa sumur tua yang ditemukan pada gang 3 dengan ukuran diameter $60 \mathrm{~cm}$ dengan lapisan dinding sumur terbuat dari batuan padasyang tersusun melingkar. Struktur dalam sumur tersebut memiliki ketebalan $6 \mathrm{~cm}$, lebar $15 \mathrm{~cm}$, dan panjang saf batu $60 \mathrm{~cm}$, dengan kedalaman sumur 2,4 m.

3. Rumah kayu

Rumah kayu pada Kampung Lawang Seketeng merupakan rumah yang seluruhnya dilapisi oleh kayu, dalam rumah tersebut masih memiliki bekas tembakan dari pesawat tempur pada atap seng yang saat ini masih dirawat oleh warga local Kampung Lawang Seketeng. Rumah tersebut di bangun pada tahun 1930 yang saat ini menjadi tempat wisata.

4. Rumah jengki

Terdapat rumah jengki dalam kampung tersebut yang merupakan rumah dengan rancangan dari arsitektur Belanda pada tahun 1930-an. Sampai sekarang rumah jengki masih menyimpan bentuk asli serta isi rumah di dalamnya. Pada tahun 2018, rumah tersebut dijadikan tempat untuk shooting Film Terbang Menembus Langit dengan memperlihatkan suasana asli rumah kuno pada tahun 1930.

5. Rumah puing

Rumah puing merupakan rumah saat jaman penjajahan yang terkena tembakan dari pesawat tempur pada tahun 1930-an. Saat ini rumah tersebut masih tersisa pondasi rumah dengan pilar-pilar besar, lengkungan diatas pintu yang menunjukkan desain rumah Belanda klasik. Rumah puing tersebut tidak memiliki atap sehingga langsung tembus dengan langit sehingga rumah puing saat ini menjadi tempat wisata bagi pengunjung untuk mengabadikan foto dengan rumah saat penjajahan.

6. Makam Syekh Zen Zaini Assegaf

Terdapat wisata religi dalam Kampung Lawang Seketeng dengan adanya makam ulama dan didalam area makam tersebut terdapat lumpang batu besar. Hal tersebut menambah jumlah pengunjung dalam wisata religi di Kampung Lawang Seketeng.

7. Makam Mbah Pitono

Wisata religi yang kedua yaitu dengan adanya makam dari Mbah Pitono yang merupakan salah satu guru ngaji dari Presiden Soekarno waktu kecil. Adanya leluhur dapat menambah jumlah pengunjung dari segi wisata religi di kampung lawang seketeng. Asal usul dari Mbah Pitono sendiri menambah daya tarik dari pengunjung untuk berwisata edukasi dengan sejarah dari Presiden Soekarno.

8. Langgar Dukur Kayu

Wisata sejarah bernuansa religi pada Kampung Lawang Seketeng tersebut merupakan ikon yang menjadi ciri khas pertama dalam mengembangkan kampung wisata. Langgar dukuh kayu merupakan 
mushola yang didirikan sekitar bulan Januari tahun 1893, hal tersebut dibuktikan dengan adanya tulisan arab pada dinding mushola dengan kalimat "Awitipun jumeneng puniko langgar tahun 1893 sasi satunggal" yang artinya, pembangunan langgar dimulai pada Januari 1893.

Langgar dukur kayu saat ini berusia 126 tahun dan bangunan tersebut terdiri dari 2 lantai yang terletak di gang 6 Kampung Lawang Seketeng. Lantai bawah merupakan museum dan tempat pertemuan warga Kampung Lawang Seketeng dan terdapat peninggalan barang sejarah dari mushola tersebut, langgar dukuh kayu merupakan mushola yang merupakan tempat mengaji dari Presiden Soekarno dengan salah satu guru ngajinya yaitu Mbah Pitono. Peninggalan barang sejarah pada mushola tersebut terdiri dari kentongan yang dibuat pada tahun 1890-an, prasasti mimbar, grendel kuno, Al-quran kuno yang ditemukan di langgar kuno dengan memiliki keunikan yaitu pada lapisan Al-quran ini terbuat dari kulit dan tulisan tangan asli dan pada tiap halaman tertera watermark Kerajaan Belanda dan pada mimbar di mushola tersebut terdapat cungkup yang unik terdapat ukiran di setiap sudutnya. Watermark merupakan sebuah tulisan atau logo yang digunakan sebagai tanda pengenal identitas dari pembuat karya tersebut. Watermark pada Al-quran di langgar dukur kayu akan terlihat ketika diberi cahaya yang sangat terang. Saat ini mushola langgar dukur kayu masih aktif digunakan oleh leluhur kampung lawang seketeng. Keunikan mushola tersebut tampak dari luar yaitu desain dari bangunan mushola tersebut menyerupai sisik ikan dan seluruh lapisan dinding pada mushola langgar dukur kayu terbuat dari kayu jati. Berawal dari langgar dukur kayu inilah Kampung Lawang Seketeng dikenal oleh masyarakat, di mulai dari wisata religi sebagai peninggalan jejak Wali Songo yang kemudian telah ditelusuri oleh peneliti sejarah atau arkeolog.

\section{Potensi Kuliner Khas Kampung Lawang Seketeng}

Selain dari wisata sejarah dan wisata edukasi pada Kampung Lawang Seketeng yang telah ditemukan dan dijelaskan oleh peneliti, terdapat potensi kuliner yang saat ini berkembang cukup pesat untuk dapat meningkatkan jumlah kunjungan dari wisatawan dengan adanya kuliner khas dari Kampung Lawang Seketeng (Hakim, 2019). Tepat di depan langgar dukur kayu terdapat sentra kuliner yang merupakan tempat pusat warga lokal berjualan makanan khas dari Kampung Lawang Seketeng. Sentra kuliner tersebut buka pada pukul 10.00 hingga 23.00 WIB. Potensi kuliner dari Kampung Lawang Seketeng dapat meningkatkan jumlah pengunjung di kampung tersebut karena wisatawan tertarik dengan makanan khas tersebut. Pada sentra kuliner Kampung Lawang Seketeng juga dapat dijangkau dengan aplikasi online yang memudahkan wisatawan atau masyarakat luar yang tidak perlu harus mengunjungi Kampung Lawang Seketeng untuk membeli makanan khas yang menjadi keunggulan dari kampung wisata tersebut. Terdapat beberapa kuliner khas utama yang sampai saat ini menjadi keunggulan dari warga lokal yang menjadi daya tarik wisatawan yaitu:

a. Sate manggul khas Kampung Lawang Seketeng

Sate manggul merupakan sate ayam dengan irisan lontong yang dibaluri bumbu manggul kental berwarna kuning yang mirip dengan keju serta terdapat srundeng kelapa di atasnya. Sate manggul merupakan makanan khas Pulau Madura dan sebagai besar warga lokal Kampung Lawang Seketeng berasal dari Madura sehingga kuliner yang ada di kampung tersebut merupakan makanan khas dari Pulau Madura. Sate manggul di Kampung Lawang Seketeng dijual perporsi seharga Rp 12.500,00 harga tersebut berbeda dengan harga perporsi yang tersedia di aplikasi online dengan menambah Rp 2.000,00 di setiap menunya. Sate menggul merupakan makanan khas dari Kampung Lawang Seketeng yang menjadi kuliner utama dari wisatawan atau masyarakat lainnya.

b. Rujak topak asli warga Kampung Lawang Seketeng

Rojak topak atau yang biasa disebut dengan rujak topak merupakan makanan yang berasal dari Pulau Madura. Rujak topak merupakan rujak yang sekilas mirip dengan rujak cingur, perbedaan dari rujak topak sendiri terdapat kecambah dan kacang panjang yang direbus dan terdapat ciri khas dari rujak topak yaitu pada rujak tersebut menggunakan petis madura, tidak hanya itu dalam rujak topak juga terdapat irisan tahu, tempe, serta irisan timun dan rujak topak menggunakan peyek yang dikremeskan sebagai baluran diatasnya. Pengertian dari topak sendiri adalah ketupat, pada makanan ini dinamakan rujak topak karena pada makanan tersebut bahan utamanya adalah ketupat. Hal tersebut 
yang menjadi daya tarik dari masyarakat terhadap makanan khas Kampung Lawang Seketeng. Rujak topak perporsi tersebut seharga $\mathrm{Rp} 8.000,00$ dan sampai saat ini menurut pengelola rujak topak masih memiliki peminat dari aplikasi online.

c. Martabak mie jajanan khas Kampung Lawang Seketeng

Martabak mie atau Martabak Wajik merupakan jajanan yang terbuat dari tepung sebagai lapisan luar dengan isian mie serta tambahan ikan yang berbeda-beda. Pada kuliner khas dari Kampung Lawang Seketeng terdapat beberapa jenis martabak mie yang berbeda-beda yaitu martabak daging, martabak pedas, martabak usus. Harga dari martabak tersebut adalah Rp 2.500,00 martabak tersebut juga merupakan jajanan khas madura yang dikarenakan warga lokal dari Kampung Lawang Seketeng sebagian besar berasal dari Pulau Madura.

Ketiga kuliner tersebut merupakan kuliner utama sebagai makanan khas dari Kampung Lawang Seketeng dengan jumlah peminat yang dapat meningkatkan jumlah pengunjung di kampung tersebut. Potensi kuliner ini dapat menambah pendapatan dari warga lokal Kampung Lawang Seketeng yang sebagian besar pekerjaannya hanya bergantung pada sentra kuliner di Kampung Lawang Seketeng. Ketiga kuliner utama tersebut juga disajikan saat terdapat acara pertemuan maupun acara yang diadakan di Kampung Lawang Seketeng maupun terdapat festival kuliner di Kota Surabaya. Kuliner tersebut merupakan strategi dalam memperkenalkan Kampung Lawang Seketeng dengan berbagai macam kuliner khas yang dimiliki. Tidak hanya tiga kuliner khas, warga lokal Kampung Lawang Seketeng juga memiliki lainnya yang juga merupakan kebiasaan dari Kampung Lawang Seketeng dan diadakan hanya setahun sekali saat lebaran. Pada saat lebaran seluruh warga lokal Kampung Lawang Seketeng membuat kuliner yang sama, hal tersebut dinamakan sebagai kuliner adhun. Kuliner adhun berasal dari Madura dan seluruh warga Kampung Lawang Seketeng serentak membuat adhun secara besar-besaran dan bersamaan. Kebiasaan tersebut telah dilakukan setiap tahun seperti pada saat hari Raya Idul Fitri dan Hari Raya Idul Adha. Kuliner adhun merupakan daging ayam kampung dengan bumbu rempah-rempah dan disajikan dengan nasi kepal yang dibungkus dengan daun pisang. Festival adhun merupakan strategi dari Kampung Lawang Seketeng khususnya dari tim pengelola untuk memperkenalkan kuliner yang ada di Kampung Lawang Seketeng, karena pada kegiatan acara tersebut seluruh warga yang membuat masakan adhun, kemudian akan dibagikan ke masyarakat sekitar Kampung Lawang Seketeng. Kegiatan tersebut serentak dilakukan oleh seluruh warga kampung sebagai tradisi yang dilakukan setiap tahun dan diadakan pada saat Lebaran.

\section{B. Tahapan Destinasi branding oleh Kampung Lawang Seketeng}

Destinasi branding merupakan usaha dalam mengomunikasikan suatu destinasi pariwisata yang telah disusun dan terorganisir (Istanto et al., 2016). Ditunjukkan adanya teori dari Morgan dan Pritchard, destinasi branding merupakan upaya dari suatu destinasi ataupun tempat wisata dalam membangun competitive identity, dengan cara mengelola reputasi dari destinasi yang dapat dipercaya oleh marketplace. Destinasi branding memberikan diferensiasi dengan destinasi wisata lain di sekitar Kampung Lawang Seketeng sehingga dapat meninggalkan kesan di benak para wisatawan yang akan menjadikannya sebagai salah satu tujuan wisata utama mereka. Hal tersebut dibuktikan oleh penelitian dari Amelia Ayu Dewanti dengan judul tahapan destinasi branding dalam meningkatkan jumlah pengunjung. Destinasi branding mampu mengelola benak wisatawan dengan baik, karena dalam benak wisatawanlah persaingan dengan destinasi lain dapat berlangsung (Yoeti, 1996).

Pada artikel ini penulis menggunakan teori destinasi branding dengan melihat lima tahapan yang harus dilakukan Kampung Lawang Seketeng dan peneliti telah melakukan observasi serta mengamati warga lokal tersebut. Lima tahapan destinasi branding menurut Morgan \& Pritchard dalam jurnal skripsi (Dewiyanti, 2016) tahapan tersebut adalah sebagai berikut :

1. Riset pasar dalam strategi analisis kampung wisata kuliner

Pada tahap pertama dalam destinasi branding, yang merupakan kegiatan pemetaan potensi dari Kampung Lawang Seketeng di hadapan konsumen pasar atau masyarakat, kegiatan dalam pemetaan potensi pasar atau target wisatawan mencakup apa saja yang dapat dikembangkan dengan menyusun 
strategi serta membuat program-program pada kampung wisata di Lawang Seketeng. Di antaranya mengidentifikasi kebutuhan dari pengunjung, menganalisa peluang di pasar atau target dari pengunjung, menciptakan produk keunggulan yang menjadi ciri khas untuk dapat membedakan Kampung Wisata Lawang Seketeng dengan kampung wisata lainnya, hal tersebut dapat menambah jumlah pengunjung dari bidang edukasi maupun wisata kuliner di Kampung Lawang Seketeng. Produk yang diciptakan sesuai dengan permintaan pasar dan dapat mencakup kebutuhan dari warga lokal sendiri, menentukan nilai produk maupun jasa dari Kampung Lawang Seketeng.

Adapun strategi dari tim Pokdarwis dalam mengembangkan destinasi branding pada wisata kulinernya. Kampung Lawang Seketeng merupakan kampung wisata heritage yang dikenal sebagai kampung masa kecil Presiden Soekarno dan dibenarkan oleh tim pengelola atau yang disebut sebagai tim pokdarwis dalam wawancara yang dilakukan di Kampung Lawang Seketeng dengan Pak Tono selaku Ketua RW dan Tim Pokdarwis "Presiden pertama yaitu Soekarno lahir di Kampung Lawang Seketeng Surabaya ini pada tanggal 6 Juni 1901 dan telah dibuktikan dengan adanya peninggalan barang serta tempat sejarah dari Soekarno dan dibenarkan oleh pihak keluarga" ujar Tono, selaku Tim Pokdarwis. Kampung Lawang Seketeng diresmikan pada hari Senin 11 November 2019, setelah peresmian tersebut tim pengelola dengan dibantu oleh komunitas Love Suroboyo untuk mengembangkan strategi dan membuat program kampung wisata untuk meningkatkan jumlah pengunjung dengan potensi yang dimiliki.

Potensi yang dimiliki Kampung Lawang Seketeng merupakan modal dalam melakukan strategi untuk mengembangkan destinasi branding menjadi daya tarik dimata pengunjung maupun wisatawan, di antaranya sebagai berikut :

a. Mengembangkan wisata kuliner di pujasera yang terletak tepat di depan langgar dukur kayu gang 6 dengan ciri khas kuliner yang dimiliki warga lokal di Kampung Lawang Seketeng yaitu sate manggul, rujak topak, dan martabak mie. Ketiga kuliner khas tersebut merupakan potensi yang sampai saat ini masih memiliki banyak peminat dengan adanya aplikasi online pembeli tidak harus mengunjungi tempat wisata melainkan hanya memesan makanan melalui aplikasi online. Hingga pada bulan April 2020 ,

"ketiga makanan ini masih aktif dan masih menerima banyak pesanan melalui aplikasi driver online dan apalagi kuliner martabak mie kita masih menerima pesanan untuk acara di perkantoran" (wawancara 30 Mei 2020)

b. Membuat program kuliner dengan mengadakan acara yang diselenggarakan oleh Kampung Lawang Seketeng bertempat di sentra kuliner atau pujasera dengan mengundang UKM-UKM di kampung wisata Surabaya.

c. Kuliner Adhun merupakan strategi yang dilakukan oleh Tim Pokdarwis dalam mengembangkan wisata kuliner Kampung Lawang Seketeng. Kegiatan tersebut dilakukan setiap satu tahun sekali pada saat lebaran hari Raya Idul Fitri. Kegiatan yang disebut sebagai masak bareng adhun merupakan kegiatan rutin setiap tahun dari warga RT 06 yang sebagian besar adalah orang Madura. Adhun merupakan makanan berasal dari Madura dengan menandakan warga lokal dari Kampung Lawang Seketeng sebagian besar merupakan orang asli Madura. Menurut Bapak Andre yang merupakan Tim Pokdarwis memaparkan.

" kalau adhun kita sudah lama menerapkan kegiatan masak bareng ini karna sudah menjadi tradisi dari warga kampung RT 06 sini, setiap lebaran semua warga masak adhun di depan rumah mereka. Setelah selesai adhun akan dibagian ke warga lain yang tidak memasak dan juga warga kampung sebelah dan Kuliner adhun sudah terkenal di kampung lawang seketeng ini" (Wawancara 30 Mei 2020)

Dalam kuliner adhun sendiri, dari pemaparan Pak Andre, masak bareng Adhun ini dilakukan serentak oleh warga RT 06, masakan tersebut akan dibagikan kepada masyarakat sekitar Kampung Lawang Seketeng maupun warga lokal yang tidak membuat makanan Adhun serta saling menukar kepada warga yang memasak adhun.

d. Menurut Bapak Andre Tim Pokdarwis, 
"kampung lawang seketeng adalah kampung sejarahnya kota Surabaya dengan adanya

Presiden Soekarno lahir di kampung ini" (wawancara, 30 Mei 2020)

Dari pemaparan tersebut dapat menjadi daya tarik dari wisatawan, komunitas sejarah, dan media untuk tetap mengikuti Kampung Lawang Seketeng.

e. Setiap satu bulan sekali, tim pokdarwis mengadakan acara di Kampung Lawang Seketeng dengan mengundang para komunitas, media, serta masyarakat selain Kampung Lawang Seketeng. Hal ini bertujuan untuk menambah jumlah pengunjung dan memperkenalkan potensi yang ada di Kampung Lawang Seketeng.

f. Mengikuti festival kuliner maupun acara yang diselenggarakan oleh pemerintah Kota surabaya, yang mana setiap mengikuti kegiatan acara tersebut perwakilan dari Kampung Lawang Seketeng selalu menggunakan kostum sebagai tanda pengenal yang dinamakan sebagai "baju keteng" merupakan ciri khas pakaian sebagai pembeda dengan kampung wisata lainya. Baju keteng merupakan baju lengan pendek berwarna putih dengan nuansa warna pudar menandakan pakaian dari arek suroboyo dalam masa penjajahan.

2. Pengembangan potensi identitas dari Kampung Wisata Lawang Seketeng

Pada tahap kedua destinasi branding ini merupakan fase dalam pengembangan identitas brand dari Kampung Lawang Seketeng yang meliputi ekspresi visual dari brand yang dikomunikasikan ke dunia luar, dan termasuk nama, logo, dan tagline. Kampung Wisata Lawang Seketeng merupakan pemilihan nama agar mudah diingat. Logo serta tagline dari Kampung Lawang Seketeng masih menggunakan gambar dari langgar dukur kayu, dimana pada tersebut menurut tim pokdarwis di kampung sendiri mereka dan warga lokal menganggap bahwa dengan adanya langar dukuh kayu masih mengangkat eksistensinya dan dapat memberikan keuntungan bagi wisata kuliner. Sehingga terdapat keterkaitan dari langgar dukur kayu yang dianggap sebagai icon dari Kampung Lawang Seketeng dan ditambah dengan wisata kuliner sebagai ciri khas dari kampung tersebut untuk dapat menjadi buah tangan serta dikenal oleh wisatawan maupun masyarakat luar saat berkunjung ke Kampung Wisata Lawang Seketeng.

\section{Pengenalan potensi kampung wisata}

Tahap ketiga ini, merupakan strategi dari branding dari Kampung Lawang Seketeng dalam menentukan target wisatawan dan pemilihan media sebagai bahan komunikasi pemasaran dari branding tersebut. Dalam tahapan ini alat bantu dalam destinasi branding untuk memasarkan wisata kuliner yang ada di Kampung Lawang Seketeng sangatlah diperlukan untuk komunikasi brand, yaitu media komunikasi pemasaran dimana pesan tersebut bertujuan untuk menginformasikan, membujuk, dan mengingatkan wisatawan, langsung ataupun tidak langsung tentang wisata sejarah, religi dan wisata kuliner yang saat ini sedang dikembangkan. Berbagai macam media yang digunakan dari tahap brand launch adalah sebagai berikut :

a. Periklanan yaitu memanfaatkan ruang media yang ada pada elektronik, media cetak, dan media online untuk menyampaikan informasi seputar destinasi wisata Kampung Lawang Seketeng. Pada setiap kegiatan yang diselenggarakan oleh warga lokal, tim pokdarwis telah bekerja sama dengan media online yaitu kumparan.com dan antaranews.

"Untuk saat ini kita memiliki partner media dari kumparan news dan kumparan.com, disetiap acara yang kita selenggarakan disini"

b. Direct marketing merupakan pemanfaatan dari beberapa media iklan untuk menarik wisatawan, dan menimbulkan respons positif sehingga pengunjung tersebut tertarik untuk mendatangi atau memesan kuliner di Kampung Lawang Seketeng. Kampung Lawang Seketeng telah bekerja sama dengan PT. HM Sampoerna Surabaya, Provider Telkomsel, Provider Indosat. Hal tersebut bertujuan untuk mempermudah tim pokdarwis memasarkan serta mendapat bantuan dalam menyelenggarakan kegiatan acara tersebut. Beberapa komunitas sejarah sering mengunjungi Kampung Lawang Seketeng 
untuk melihat perkembangannya, termasuk juga komunitas dari Love Suroboyo yang merupakan rekan kerjasama untuk mengembangkan, memberikan edukasi kepada warga lokal, serta membantu proram kegiatan acara yang diselenggarakan di Kampung Lawang Seketeng. Media yang dikelola oleh tim pokdarwis sendiri yaitu media sosial facebook dan instagram, serta terdapat website. Nama dalam media Kampung Lawang Seketeng yaitu Wisata Langgar dukur kayu, di mana nama tersebut menurut anggota dari tim pokdarwis dapat meningkatkan jumlah pengunjung dengan eksistensinya yang dimiliki, sehingga langgar dukur kayu dipercaya dapat memberikan keuntungan dari warga Kampung Lawang Seketeng. Media sosial dari Kampung Lawang Seketeng bernama "langgar dukur kayu", dimana menurut tim pokdorwis alasan menggunakan nama tersebut karena langgar dukur merupakan ikon yang dimiliki oleh Kampung Lawang Seketeng dengan wisata sejarah mengenai asal usul Soekarno, sehingga nama yang dicantumkan yaitu langgar dukur kayu. Media sosial yang dimiliki yaitu facebook, youtube, dan website.

c. Sales promotion, merupakan kegiatan dengan waktu jangka pendek di mana wisatawan dapat membuat sebuah program dengan tujuan mempromosikan destinasi wisata di Kampung Lawang Seketeng. Seperti halnya pada tahun 2018, Kampung Lawang Seketeng dijadikan tempat untuk shooting film "Terbang Menembus Langit" (petisi.co, diakses pada tanggal 21 juni 2020). Hal tersebut dapat memperkenalkan kondisi daru beberapa rumah tua yang ada di Kampung Lawang Seketeng.

d. Public relation merupakan upaya dalam membangun dan mempertahankan untuk saling mengerti serta memahami dari warga dengan masyarakat lain. Kampung Wisata Lawang Seketeng memiliki pengelola yang dinamakan sebagai Tim Pokdarwis atau Sadar Wisata, di mana pada tim tersebut bertugas untuk mengelola, mewakili, dan memberikan edukasi bagi warga lokal untuk sadar dan merubah kebiasaan buruk menjadi kegiatan wisata yang dilakukan di area Kampung Lawang Seketeng. Dari Bapak Tono sendiri memaparkan,

"kampung ini tidak memiliki karang taruna, sehingga kami membentuk tim pokdarwis dengan tiga tim, dan masing-masing dari anggota ini memiliki tugas yaang berbeda-beda" (wawancara, 30 Mei 2020)

Pokdarwis dibentuk pada tanggal 13 Juli 2019, dari pemaran tersebut tujuan dibentuknya pokdarwis sebagai tim pengelola atau tim sadar wisata di Kampung Lawang Seketeng adalah memperkenalkan destinasi wisata yang ada di kampung lawang seketeng khususnya tentang peninggalan sejarah serta wisata kuliner yang menjadi ciri khas dari kampung lawang seketeng.

\section{Representasi Kampung Lawang Seketeng}

Tahap destinasi branding yang keempat ini merupakan suatu usaha untuk mengintegrasikan semua pihak yang terlibat dalam pembentukan suatu brand, sehingga destination branding tersebut dapat berhasil dilakukan. Semua pihak yang terlibat dalam mengembangkan Kampung Lawang Seketeng tersebut adalah dari warga lokal sendiri, komunitas sejarah, stakeholder, pemerintah, serta wisatawan yang tertarik dengan Kampung Lawang Seketeng. Masyarakat yang tinggal di kampung tersebut, terdapat 3 macam suku di dalamnya. Terdapat Suku Cina, Jawa, dan Madura perbedaan suku tersebut merupakan tantangan dari tim pokdarwis yang merupakan pengelola sekaligus penanggung jawab dari Kampung Wisata Lawang Seketeng untuk merubah pola pikir serta kebiasaan warga tentang adanya kampung wisata. Berikut pemaparan dari Bapak Tono mengenai kerjasama dengan komunitas maupun pemerintah :

"kami bekerjasama dengan komunitas-komunitas sejarah, dan saat ini kami dibantu dengan komunitas love suroboyo hingga saat ini mereka masih berpartisipasi jika ada acara yang kami selenggarakan. Dengan pemerintah juga oleh dinas pariwisata Kota Surabaya yang rutin membahas perkembangan kampung wisata khususnya kami aktif dalam kegiatan rutin tersebut" (wawancara, 30 Mei 2020) 
Dari pemaparan tersebut peniliti melihat masih adanya kerjasama yang saat ini terjalin dari komunitas, pemerintah dan media dalam berperan untuk mengembangkan serta mempromosikan kampung wisata yang baru diresmikan pada tahun 2019 kemaren. Menurut Bapak Tono sendiri, Kampung Lawang Seketeng merupakan kampung wisata yang baru diresmikan oleh pemerintah Kota Surabaya, sehingga membutuhkan wawasan dalam mengembangkan kampung tersebut.

Berdasarkan uraian-uraian diatas, peneliti melihat bahwa disini pengelola mengimplementasikan proses dan tahapan destinasi branding menurut Morgan \& Pritchard dalam penelitian yang berjudul tahapan destinasi branding dalam meningkatkan jumlah pengunjung (Dewiyanti, 2016) yaitu brand implementation di mana pada fase ini pengelola melakukan kerjasama dan mengintegrasikan semua pihak yang terlibat dalam proses branding Kampung Lawang Seketeng dan pemasaran bersama dengan masyarakat lokal, komunitas sejarah khususnya dari komunitas Love Suroboyo, serta pemerintah dari Dinas Pariwisata Kota Surabaya.

\section{Evaluasi dan pemantauan dari respon pengunjung}

Tahap kelima dalam destination branding yaitu mengevaluasi, monitoring, dan melihat respons dari pengunjung terhadap Kampung Lawang Seketeng. Pada tahap ini dilakukan usaha untuk memonitoring apakah ada penyimpangan yang terjadi, kekurangan dan sebagainya dalam membranding destinasi kampung wisata ini, dengan cara memantau respons dari audience dari menindaklanjuti jika terdapat wisatawan ataupun pengunjung yang perlu ditanggapi. Dalam hal ini pengelola yaitu tim POKDARWIS Kampung Lawang Seketeng melakukan dan mengimplementasikan tahapan dengan memonitor, dan memperhatikan respon dari pengunjung pada Kampung Wisata Lawang Seketeng sendiri, di sini pengelola memastikan apakah pada pelaksanaan di lapangan terdapat kekurangan maupun kritik dan saran dari pengunjung. Kegiatan ini dilakukan dengan cara menampung segala keluhan dari masyarakat lokal maupun wisatawan, mulai dari kritik dan saran dari pengunjung Kampung Lawang Seketeng.

Pada bulan Februari 2020, Negara Indonesia terkena wabah virus Corona yang biasa disebut Covid-19. Sehingga seluruh daerah di Indonesia terdampak dari adanya covid-19 termasuk kota Surabaya yang merupakan kota terbesar di Indonesia, hal tersebut berdampak dari bidang sosial, ekonomi, dan kesehatan. Pemerintah menghimbau masyarakat untuk mengurangi segala aktivitas dengan melakukan pembatasan kegiatan, yang bertujuan untuk memutus rantai penyebaran virus covid-19 dan seluruh kegiatan tersebut diganti dengan melakukan pekerjaan hanya di rumah atau melalui online (Interaktif.kompas.id, diakses pada 23 Juni 2020). Tim pokdarwis dari Kampung Lawang Seketeng oleh Bapak Tono memaparkan :

"adanya covid-19 ini pengunjung disini sangat menurun drastis, dan sangat berdampak kepada warga lokal yang pekerjaanya hanya bergantung pada kampung ini. Banyak juga dari warga mengeluhkan sehingga dari kita sebagai tim pengelola mencari solusi untuk kuliner di kampung ini tetap berjalan" (wawancara, 30 Mei 2020)

Kampung Wisata Lawang Seketeng memiliki jam buka pada hari Sabtu, Minggu, dan Senin karena hari tersebut merupakan hari efektif dengan peningkatan jumlah pengunjung saat berwisata di Kampung Lawang Seketeng. Berdasarkan pemaparan yang dijelaskan oleh Bapak Tono, memperlihat adanya monitoring dari pengelola dari warga lokalnya sendiri dan memantau wisatawan yang mengunjungi Kampung Lawang Seketeng, serta dapat mereview dan memberikan evaluasi yang berupa solusi untuk warganya sendiri. Bapak Andre juga memaparkan mengenai wisata kuliner Kampung Lawang Seketeng.

“ berjalan setelah peresmian kampung ini, kita telah melihat beberapa potensi yang cukup banyak peminat dan melihat dari wisata kuliner dari kami, ternyata mampu meningkatkan jumlah peminat dan pengunjung setelah adanya langgar dukuh" (Wawancara, 30 Mei 2020)

Strategi dari pengelola untuk mengantisipasi adanya situasi wabah covid-19 yaitu dengan mempromosikan melalui aplikasi online mulai dari GoFood, Grabfood, serta media sosial guna memasarkan kuliner khas dari Kampung Lawang Seketeng rujak topak, sate manggul, dan martabak mie. Beberapa dari warga lokal yang pekerjaanya diluar Kampung Lawang Seketeng juga ikut 
membuka usaha kuliner seperti nasi goreng, mie pedas, dan jajanan lainya. Menurut pengelola dari Bapak Tono saat ini dengan adanya wabah covid-19 wisata kuliner di Kampung Lawang Seketeng tetap berjalan dengan normal dengan beralihnya semua kegiatan kuliner melalui media online dan aplikasi online atau driver online dapat mempermudah konsumen untuk tetap membeli makanan yang memiliki peminat cukup banyak dari wisatawan maupun masyarakat lainnya. Strategi yang dilakukan yaitu dengan memberikan promo disetiap pembelian dan jam buka yang diperbanyak sehingga dari wisata kuliner saat ini tetap menambah pendapatan dikondisi Covid-19 saat ini. Hal ini merupakan evaluasi dari pengelola Kampung Lawang Seketeng untuk dapat mengantisipasi adanya kondisi wabah covid-19 tersebut.

\section{SIMPULAN}

\section{Simpulan}

Destinasi branding merupakan usaha dalam mengomunikasikan suatu destinasi pariwisata dengan tujuan untuk memberikan persepsi dan pandangan kepada wisatawan mengenai kampung wisata tersebut. Kampung Lawang Seketeng sebagai wisata kuliner dapat disimpulkan bahwa destinasi wisata dari Kampung Lawang Seketeng memiliki tiga jenis yang berbeda yaitu wisata religi, wisata sejarah, dan wisata kuliner. Melihat respon pengunjung dan jumlah peminat dari wisatawan yang mendatangi Kampung Lawang Seketeng menurut pengelola yang telah dipaparkan yaitu, wisata kuliner dari Kampung Lawang Seketeng hingga saat ini memiliki jumlah peminat yang cukup banyak. Berawal dari wisata sejarah dengan adanya langgar dukur kayu yang merupakan tempat mengaji dari Presiden Soekarno dan bentuk bangunan yang unik merupakan tempat ikon dari Kampung Lawang Seketeng sehingga dari perawalan yang memberikan keuntungan tersebut wisata kuliner di Kampung Lawang Seketeng dapat dikenal sekaligus mampu membranding destinasinya sebagai wisata kuliner. Kampung Lawang Seketeng memiliki tiga makanan ciri khas yang masih banyak peminatnya hingga saat ini yaitu sate manggul, rujak topak, dan martabak wajik atau martabak mie. Sebagian besar makanan khas dari Kampung Lawang Seketeng berasal dari Madura yang dikarenakan warga lokal kampung tersebut berasal dari Pulau Madura. Melalui lima tahapan destinasi branding menurut Morgan \& Pritchard yang dijelaskan dalam penelitian Ayu Via Dewiyanti tahun 2016 yaitu riset pasar dan strategi analisis, pengembangan identitas yang dimiliki, pengenalan objek kampung wisata, representasi dari kampung wisata, evaluasi dengan pemantauan respon pengunjung. Wisata kuliner di Kampung Lawang Seketeng dapat diperkuat dengan adanya tiga makanan unik dan menjadi ciri khas dengan jumlah peminat cukup banyak. Berdasarkan hasil dari penelitian ini dapat diketahui dengan strategi untuk mengembangkan wisata kuliner, dan dengan adanya kondisi wabah covid-19 yang dapat merugikan banyak warga hingga saat ini. Pengelola dari Kampung Lawang Seketeng mengembangkan kuliner tersebut dengan melalui online yaitu mempromosikan melalui aplikasi ojek online serta media sosial yaitu Facebook. Kurangnya tenaga kerja juga dapat mempengaruhi kinerja dalam mengembangkan Kampung Wisata Lawang Seketeng sehingga kurang aktifnya penggunaan media sosial yang dapat mengembangkan wisata kulinernya di dunia maya.

\section{Saran}

Sebagai kampung wisata yang telah diresmikan oleh pemerintah, terdapat peraturan dalam mengelola dan mengembangkan kampung wisata tersebut. Berdasarkan temuan yang diperolah dari hasil penelitian ini, peneliti berharap dapat mengkaji lebih dalam tentang strategi dan program dengan tujuan memberikan edukasi kepada warga dari Kampung Lawang Seketeng mengenai destinasi branding dalam wisata kuliner dari kampung lawang seketeng, hal tersebut dapat meningkatkan kinerja dan merubah pola pikir dari warga lokal sendiri. Adapun saran yang diberikan oleh peneliti yaitu peneliti berharap kepada Tim POKDARWIS Kampung Lawang Seketeng dapat mengembangkan potensi yang dimiliki dengan cara aktif menyelenggarakan kegiatan acara dengan maksud untuk dapat meningkatkan jumlah pengunjung dalam wisata kuliner yang dimiliki. Peran dari media sosial sangatlah penting di era saat ini untuk mempromosikan dan menyebarkan informasi tentang destinasi branding Kampung Lawang Seketeng sebagai wisata kuliner. Sehingga wisatawan 
atau masyarakat dapat mudah mengetahui dan menerima informasi pembaruan dari wisata kuliner Kampung Lawang Seketeng.

\section{DAFTAR PUSTAKA}

Anggraini, N. N. (2018). Destinasi Branding bawean sebagai pulau wisata. Mathematics Education Journal, 1(1), 75. https://doi.org/10.29333/aje.2019.423a

Anholt, s. (2007). Competitive Identity: The new brand management for nations. Palgrave Macmillan.

Anonim. (2009). UU No. 102009 Tentang Kepariwisataan. Undang Undang Tentang Kepariwisataan. https://www.kemenparekraf.go.id/index.php/post/undang-undangrepublik-indonesia-nomor-10-tahun-2009

Antara, M., \& Arida, N. S. (2015). Panduan pengelolaan desa wisata berbasis potensi lokal. Konsorium Riset Pariwisata Universitas Udayana, 23.

Ariando, V. (2015). Destination Branding Kepulauan Seribu. (Studi Kasus Destination Branding Kepulauan Seribu Dalam Upaya Mengembangkan Destinasi Wisata Bahari Internasional.

Dewi, A. F. (2009). Destination Branding Kampung Sate ambal resmi.

Dewiyanti, A. . V. (2016). tahapan destinasi branding dalam meningkatkan jumlah pengunjung.

Farhanas, S. (2018). Destination branding gunung pinang sebagai tujuan wisata di kabupaten serang.

Hakim, A. (2019, October 26). Kampung Lawang Seketeng Surabaya Jadi kampung heritage. https://www.antaranews.com/berita/1132648/kampung-lawang-seketeng-surabaya-jadidestinasi-wisata-heritage

Hasan, A. (2015). Tourism Marketing. CAPS (Center Of Academic Publishing Service).

Iskandar, S. M. (2017). PARTISIPASI KELOMPOK SADAR WISATA (POKDARWIS) DALAM MENGEMBANGKAN PARIWISATA DI KECAMATAN RAJABASA KABUPATEN LAMPUNG SELATAN.

Istanto, F. H., Somawiharja, Y., Herdinata, C., \& Kurniawan, M. N. (2016). Pengembangan potensi wisata berbasis brand destination (Studi kasus destinasi wisata budaya di Trowulan). Conference on Management and Behavioral Studies, 457-469.

Jannah, nur ika anisaul. (2019, November 13). Cicipi tiga kuliner khas kampung lawang seketeng. Tribunjatimtravel.Com. https://tribunjatimtravel.tribunnews.com/2019/11/13/cicipi-tiga-kuliner-khas-wisataheritage-kampung-lawang-seketeng-ada-sate-manggul 
Jaya, I. wayan P., \& Ariana, I. gede putra. (2009). Kepariwisataan Dalam Perlindungan Dan Pelestarian. 2009(3), 1-5.

Khairunisa, G. (2015). STRATEGI SURABAYA TOURISM PROMOTION BOARD DALAM MENJALANKAN DIPLOMASI PARIWISATA SURABAYA DENGAN BRUNEI DARUSSALAM TAHUN 2005-2008. $D k, \quad 53(9), \quad 1689-1699$. https://doi.org/10.1017/CBO9781107415324.004

Kountur, R. (2007). Metode Penelitian untuk penulisan skripsi dan tesis. PPM.

Kusuma, R. H. (2018). Analisis Potensi dan Pengembangan Desa Wisata di Kabupaten Sleman. Program Studi Geografi, Universitas Gadjah Mada.

Marpaung, H. (2002). Pengantar Pariwisata. Alfabeta.

Miles, M. (1984). Analisis Data Kualitatif (T. R. Rohidi (ed.); Terjemahan). Universitas Indonesia.

Moleong, L. J. (2007). Metode Penelitian Kualitatif. Remaja Rosda Karya.

Nuryanti, W. (2003). Pengembangan Kampung Wisata. PN Balai Pustaka.

Pendit, N. S. (2003). Ilmu Pariwisata sebuah Pengantar Perdana. Pradnya Paramita.

Priyadi, U. (1993). Mengoptimalkan Peranan Sektor Pariwisata Dalam Penerimaan Devisa Dan Sebagai Instrumen Mengentaskan Kemiskinan. 9.

Rahim, I. F. (2012). Pedoman Pokdarwis. 52.

Razzaq, M., Fitriyah, N., Faisal, M., Destinasi, S. P., \& Wisata, K. S. (2019). FUNGSI KOMUNIKASI PARIWISATA PADA KELOMPOK BAHARI MANGGAR BARU. 7(3), $140-154$.

Satriya, D. (2011). Perilaku Keorganisasian Surabaya Tourism Promotion Board. Jurnal Ilmiah Pariwisata, 16(1), 16-23.

Sugiyono. (2011). Metode Penelitian Kualiatif Kuantitatif $R \& D$. Alfabeta.

Suryawan, A. (2016). PERAN KELOMPOK SADAR WISATA (POKDARWIS) SENDANG ARUM DALAM PENGEMBANGAN POTENSI PARIWISATA.

Vasyl, D., \& Julio, M. (2014). Consumption Values Destination Evaluation in Destination Decision making. Journal of Tourism and Places, 2, 1.

Zahroh, F. (2019, October 28). Wisata heritage kampung lawang seketeng surabaya. Surabaya.Tribunnews.Com. https://surabaya.tribunnews.com/2019/10/28/wisataheritage-kampung-lawang-seketeng-surabaya-warga-bentuk-pokdarwis-dan-siap-jaditour-guide 
JURNAL ILMIAH KOMUNIKASI MAKNA

Vol.8,No.2, Agustus 2020, pp.118-133

E.ISSN:2334-4606, P-ISSN:2087-2461

http://jurnal.unissula.ac.id/index.php/makna

DOI: http://dx.doi.org/10.30659/jikm.8.2.118-133 